Gunilla Jansson*

\title{
Negotiating belonging in multilingual work environments: church professionals' engagement with migrants
}

https://doi.org/10.1515/applirev-2021-0054

Received April 8, 2021; accepted April 17, 2021;

published online May 13, 2021

\begin{abstract}
The study presented in this paper focuses on three evangelical churches in Sweden and their engagement with migrants. The goal of the study is to explore how professionals engage with migrants in their everyday work in a multilingual environment. To this end, data from interviews with church professionals are triangulated with video-recordings of their interaction with migrants in a variety of church settings. The analyses demonstrate how different dimensions of belonging are enacted in multilingual encounters through practices that allow the professionals to perform social work in an activity context where empathy is of great importance. These findings highlight the role of the church within the public sphere under the changing conditions of globalization.
\end{abstract}

Keywords: belonging; church professionals; empowerment; migrants; translanguaging

\section{Introduction}

Through the social and global development related to migration and mobility the modern workplace has become multilingual. Hence employees' realities are becoming increasingly multifaceted. The need for handling multilingualism is significant for professionals, who need to manage relationship-building talk and provide services to people with whom they do not share the same first language. The professionals in focus in the present article are working with pastoral care in multi-ethnic, suburban environments. The article focuses on three evangelical

\footnotetext{
*Corresponding author: Gunilla Jansson, Stockholm University, Stockholm, Sweden, E-mail: Gunilla.jansson@su.se
} 
churches in Sweden and how they respond to the needs of migrants, one of the most pressing issues confronting contemporary society. ${ }^{1}$

We live in an era shaped by migration and the movement of people who have been displaced across international borders by the currents of globalization. Migration is in fact the normal paradigm for many. More people are displaced in the world today than at any point since the end of World War II. Specifically, the number of people moving to Sweden has markedly increased during the last two decades. In 2015, the number of asylum seekers to Sweden was the highest ever, over 160,000 people (National Bureau of Statistics). This huge influx may represent a challenge for the receiving society, which is called to provide the newly-arrived migrants with shelter and food, and to offer some practical solutions for facilitating their integration. In 2015, when the state organizations in Sweden were overwhelmed with the number of migrants and could not adequately respond to the challenges at the time, the civic society, churches among others, helped the reception centres and eased the process of providing welfare services (Wagndal 2016).

The social engagement of churches with the public sphere, rooted in the gospel's love command (Flescherand Worthen 2007), is well documented in the literature (e.g., Miller and Yamamori 2007; Ruiter and De Graaf 2006). Despite declining attendance, churches continue to play a crucial role as providers of welfare and charity (Prochaska 2006; Salmonsson 2016; Snyder 2012; Steensland and Goff 2013).

One of the social issues where church engagement is prominent and has a long history (Marfleet 2011) concerns the inclusion of migrants, which has to do with the call placed upon Christian churches by faith-based altruism (Flescherand Worthen 2007). This concept is rooted in biblical and theological traditions, such as the great command to remember aliens and strangers, and the challenge to see Christ in the migrant and the dispossessed. Indeed, as Zink (2019) puts it, themes of migration are threaded throughout the Bible. In line with faith-based altruism, the framework of practical theology (e.g. Graham et al. 2019) invites believers to accomplish faithful actions, also termed pastoral practices. Today, we can see how biblical commands are enacted by churches

1 The category migrant, at a basic level, refers to anyone who is on the move, tourists and visitors excluded (see e.g. Snyder 2012: 9-10). The category includes asylum-seekers who are formally seeking refugee status, as well as persons whose asylum claim has been refused but continue to live in the country of destination without documents. As these categories are ambiguous and overlapping in the lived experiences of migrants, I use the term migrant in a broader sense to include features of vulnerability (which, for example, characterize underprivileged migrants) and undesirability, so that the term does not simply refer to those seeking asylum. 
through creative pastoral practices in organized, multi-staffed and agency funded projects (see overview in Snyder 2012; for Swedish examples, see Salmonsson 2016). Many of these projects involve volunteers and respond to the practical and pastoral needs of asylum-seekers by offering language classes and cooking sessions, and by helping them to find accommodation and lawyers. During the last decade, the practices of those involved in this kind of settlement work (see Chao 2020 for citizenship preparation classes; Simpson 2020 for immigration legal advice; and Gregory et al. 2013 for faith literacy classes) have attracted the attention of applied linguists.

The majority of previous studies outlined above are conducted from a theological perspective, whereas only a few focus on language and communication (Chao 2020; Gregory et al. 2013; Simpson 2020). Specifically, the research field concerning the church role in the migrant context still lacks attention to the pastoral practices of parish leaders and other church professionals working in multi-ethnic environments and to their everyday interaction with migrants. We need more investigation on how the professionals envision their role as providers of spaces for social wellbeing in the migrant context, and how they utilize linguistic resources in constructing these spaces. This study investigates how professionals in three evangelical churches in Sweden engage with migrants in their everyday work. In order to explore how the professionals engage with migrants in their everyday work in a multilingual environment, data from interviews with church professionals are triangulated with video-recordings of their interaction with migrants. The article highlights the practices through which issues of diversity and vulnerability are addressed in an activity context where empathy is of great importance.

Before presenting my data, I briefly discuss the conceptual framework of the study. An overarching term used to conceptualize the professionals' commitment as providers of social wellbeing in a migrant context is belonging. This concept is discussed in the background section below, together with translanguaging and empowerment. The latter are key analytical terms used to foreground the practices through which spaces of belonging are negotiated. In the analyses, I demonstrate how belonging is developed as a recurrent theme in the professionals' accounts of how they envision their role as members of a faith community; specifically, the professionals aim to create spaces in which the migrants can experience community. Using extracts from video-recordings of naturally occurring interaction in the churches, I then illustrate how belonging is enacted in practice. Finally, I discuss the role of the church within the public sphere under the changing conditions of globalization. 


\section{Conceptual framework}

The concept of belonging as used in previous studies is fluid (see Lähdesmäki et al. 2016 for a review). It has been used in multiple senses in contemporary research across disciplines, though some common denominators can be identified. According to Lähdesmäki et al. (2016: 242), the analytical power of belonging lies precisely in the multiplicity of dimensions that it can potentially cover. Belonging, the authors conclude, is best understood as situational relationships with other people and practises stemming from these relationships "which are fundamentally political and include emotional and/or affective orientations” (Lähdesmäkiet al. 2016: 242). In sociological studies the concept has been applied to describe the sense of attachment to a nation, a feeling of membership with a community (e.g. Bakkær Simonen 2017). It has also been used in the sense of attachment to a place, shaped by an illusion of being at home (Fauser2020). This is how Chao (2020) uses the concept in her study of church-based citizenship pedagogy for adults with a refugee background in the U.S.

In this study, I use the concept in a similar sense, but with more emphasis on its interactional aspect; that is, I use belonging to describe the interactional work that is done in order to create or negotiate spaces in which one can experience social well-being and feel embraced by the community and empowered as an enabled citizen, as well as spaces in which one can form social relationships. Negotiating spaces for belonging to a community has been emphasised in second language (L2) studies as significant for the construction and maintenance of the migrant learners' identity in new contexts (Lee 2015; Norton 2000; Pastor and De Fina 2005). These studies have shown how identity, place and belonging are constructed in and through narrative discourses. Lee (2015) describes how second language learners' narratives in a lingua franca zone (Firth and Wagner 1997) show dynamic aspects of multilingualism and multiple belonging. The co-construction of experience through joint storytelling, the author maintains, not only provides them with the opportunity to participate in their L2 but also provides them with a space for belonging in which they form social relations and identities. In a multilingual community, Lee (2015) argues, where there are differences pertaining to language, religion and culture, participants' interactions create new zones for belonging, a space (Kramsch1993) out of which a group membership emerges or a community not necessarily involving only the new cultural environment. This line of reasoning is also applicable to the migrant context in the present study.

A key analytical term used in this article to capture how these spaces of commonality are negotiated across linguistic and cultural boundaries through participants' creative practices is translanguaging (García and Wei 2014; Wei 2018). 
This concept, which has been applied to multilinguals' interaction in a variety of settings, ranging from education (e.g. García and Wei 2014) to everyday social interaction (e.g. Blackledge et al. 2015), has radically updated the theoretical tradition of multilingualism (note however that the theoretical motivation for the need of this term has recently been debated; see Wagner 2018; Wei 2018). Specifically, from a translanguaging perspective, multilingualism is understood, by the very nature of the phenomenon, as a rich source of creativity that becomes manifest in the ability to break and push boundaries between languages (cf. Wei 2018: 23). In this article, it is argued that the concept of translanguaging provides added value when approaching the complexity and the nature of multilingualism in the linguistic reality of a contemporary workplace shaped by migration and globalization (Blommaert 2010). As will be shown in subsequent analyses, in a translanguaging space, multilinguals not solely go between languages, they also go beyond language(s) (cf. Wei 2018) in that their practices draw on history, memory and experience.

Another prominent dimension covered by the concept of belonging in this article is empowerment. The term empowerment is defined by Cummins (2000) as "the collaborative creation of power" (p.44). Cummins, who applies the term to the pedagogical context of educating culturally diverse students in bilingual schooling, maintains that empowerment is generated through interaction with others. This implies, according to Cummins, that students whose sense of identity is being affirmed in their interaction with educators can participate confidently in instruction. In the present article, the term is applied to the migrant context, where it is inherently linked to issues of vulnerability. It conceptualizes the practices through which migrants are positioned as being enabled or empowered to seek knowledge and participate in networks, and to act as legitimate participants in the course of their settlement (e.g., making social contacts, self-supporting through employment) and citizenship (e.g., exercising civic rights; see Bech et al. 2017).

\section{Setting}

The setting analysed in this paper consists of three evangelical churches which I name the Hill Church, the South Church and the North Church. The churches are located in suburban municipalities, which welcome many migrants and provide support with settlement to asylum-seekers. The municipalities where the South Church and the North Church are located are long-standing migrant communities established in the 1960s and 1970s. Ethnic residential concentration is prevalent in these communities, which has resulted in the formation of minority cultures and languages rather than inclusion in the greater society. The South Church has a 
rather long history of migrant and settlement work (since the 1970s), whereas the two other churches have a shorter history (since a decade ago).

At the time of the fieldwork, all three churches were part of an integration project called "Tillsammans för asylsökandes egenmakt och deltagande" ('Together for asylum seekers' empowerment and participation'). The project was funded by government grants from the County Administrative Board (project period 2018-2019). A regional missionary evangelical organization, which has provided support to socially vulnerable people since the late eighteenth century, is the head of the project. The overarching goal of the project is to "strengthen asylum seekers' empowerment and participation by bringing knowledge, enabling mutual exchange of experiences, offering community and networking" (quote from the churches' application for funding ${ }^{2}$ ). Since the churches analysed here are so called "free churches" (i.e., churches whose economy relies on donations from their members), these funds have been vital for the scope of the churches' activities. The pastors describe their congregations as "poor" with a restricted economy. The churches have used the funds in somewhat different ways. The South Church has invested in language classes and teaching, whereas the North Church and the Hill Church have developed a variety of social activities beside language classes, such as language cafés organized as drop-in sessions for language training, cooking and baking sessions, health enhancement, interpreting and guidance with settlement in the migrants languages. These social activities are primarily based on voluntary help.

The language classes in the North Church and the South Church are conducted as study circle activities taught by teachers with pedagogical training. The classes take place in the social gathering room in the church. Participation in these classes does not qualify towards the certificate in Swedish for immigrants (or "sfi"); that is, these classes are not part of the state-funded sfi program. As such, they are not framed by curriculum and national tests. Nevertheless, in the South Church, the teachers are language teachers working in sfi schools, while in the North Church the teacher is a church member who is employed as a parish educator.

The migrants who attend the activities organized by the churches are asylumseekers, undocumented migrants without residence permit who have not access to state-funded sfi programs, and migrants with various lengths of residence in Sweden who have run into long-standing unemployment after attending the state-funded sfi-program. The activities organized by the churches, including the language classes, are in many cases the only opportunities the migrants have to practice their Swedish and to establish and maintain social contacts with the local community (here understood as all people living in a restricted area).

2 All translations of quotes from empirical data used in this article are the author's. 


\section{Method and data}

The method used in this study combines an ethnographic approach with conversation analysis (CA; Sidnell and Stivers 2013). Long-term ethnographic fieldwork provided knowledge about routine activities and especially about the practices of the church professionals. Specifically, I embrace the concern for ecological validity through ethnographically contextualized data sources (Cicourel1985, 1992).

The study is part of a larger project ${ }^{3}$ exploring the interactional ecology of language cafés. Fieldwork was carried out by the author and her two collaborators in 14 language cafés and a language class located in churches and libraries in Sweden. The present study draws on interviews, participant observations and video-recordings in the three evangelical churches mentioned above (i.e., the Hill Church, the South Church and the North Church). The fieldwork was carried out from February 2018 until June 2019 and comprises 40 visits in the churches. The researchers gained access to the field after ethical approval from the churches. All data were collected following the ethical guidelines established by the Swedish Research Council and with the approval of the Regional Committee for Research Ethics.

Audio-recorded semi-structured interviews with five employees (three pastors/parish leaders and a deacon, all ethnic Swedes, and a parish educator with Spanish heritage) in the three churches were carried out by the author. The length of the interviews varies between 30 and $70 \mathrm{~min}$. The employees were asked to describe their perspectives concerning the goals of their engagement with migrants; that is, what they envision as their Christian community's most important commitment in the migrant context. Interview data are combined with field notes taken during participant observation and with video-recordings of three of the employees' interaction with the migrants, one employee from each church (the pastor in the Hill Church, the parish educator in the North Church and the deacon in the South Church, for a total of $66 \mathrm{~h}$ ), in order to provide a rich understanding of the sites. The interactional data provide primary, observable evidence to the claims I make about the research sites based on my interpretation of ethnographic data. At the same time, ethnographic details enrich the analytical rigour of empirically based accounts of the professionals' observable conversational behaviours. Ultimately, data triangulation can shed light in particular on how the professionals construct their workplace practices and orient to them.

3 This study is part of the project "The language café as a social venue and a space for language training”. The project is funded by The Swedish Research Council (VR 2017-03628) and led by the author. Collaborators are Silvia Kunitz and Ali Reza Majlesi. 
For the purposes of the present article, the interviews were transcribed and then analysed with a thematic approach. This approach involved the identification of instances in which the professionals comment on two specific topics: their mission as members of a faith community in a migrant context and their practices when coping with a multilingual work environment. Through repeated reading of the transcripts and listening to the interviews, "negotiating spaces of belonging" arose as a recurrent, overarching theme throughout the professionals' accounts. Data excerpts from the interviews illustrating this theme were thus selected for this article.

Subsequently, the analysis focused on sequences of multilingual interaction involving: (i) the pastor in the Hill Church and a migrant from Syria; and (ii) the parish educator and the attendees in the language classes in the North Church. The video-recordings were analysed from an emic (participant-relevant) perspective with the methodological tools afforded by CA. After watching the video recordings in their entirety, sequences that show how the commitment to belonging was enacted in the pastor's interaction with the café attendees and in the language classes were identified and roughly transcribed. Data excerpts illustrative of the professionals' practices were selected for this article.

The data for the present article are presented in the form of transcripts. Data excerpts from the interviews have been translated from Swedish into English by the author; the English translation appears below the Swedish original. For the sake of readability, a middle form between written Swedish and verbatim pronunciation is used.

Data excerpts from the video-recordings have been transcribed following CA conventions for multimodal transcription (Jefferson 2004); transcription conventions are provided in Appendix 1. Each Swedish utterance is given an English translation in italics beneath it; an attempt was made to make the translations comprehensible, albeit not always altogether idiomatic. Conversational video-recorded data in Arabic have been transcribed and then translated into English by a proficient speaker of Arabic. When needed, two translation lines are provided under each line in Arabic: the first line is a gloss that follows the transcribed talk word-by-word (a list of morphological abbreviations is provided in Appendix 2); the second gloss is an idiomatic English translation.

\section{Results - creating spaces for belonging}

In the analysis below, I demonstrate how different dimensions of belonging, the overarching theme in the professionals' discourse, are invoked in their accounts of how they envision their role as members of a faith community in a migrant context. These different dimensions are empowering the vulnerable and negotiating 
belonging beyond linguistic and cultural boundaries. Using extracts from videorecordings of naturally occurring interaction in the churches, I then illustrate how these dimensions of belonging are negotiated and enacted in practice.

\subsection{Empowering the vulnerable}

Minority groups, such as asylum seekers and migrants, are vulnerable to social exclusion and segregation. The migrants in this study were in vulnerable positions insofar as they were not yet settled in the Swedish society in terms of earning their living and learning the language. After several years of residence in Sweden, many of them were still in need of help with housing and employment, and with contacts with municipalities and authorities. As the deacon in the South Church puts it, "when the municipalities and authorities cannot help any more, people seek support from the church" (quote from interview). Even if she cannot always help, the deacon reports, she is called to listen and get involved in the migrant's story, for instance through suggesting possible solutions.

Empowering the vulnerable is regarded by the church professionals as an inherent and integral part of the church social work. More precisely, empowering the vulnerable is understood as helping migrants "to experience a sense of community in the Swedish society" (interview with the pastor in the South Church) and making them feel embraced by the Swedish society "as if they were at home" (interview with the pastor in the Hill Church). Indeed, as mentioned above, the integration project for which the churches got funded aimed precisely to strengthen the migrants' empowerment and foster their participation in the Swedish society. The analysis below focuses on how this commitment is voiced and enacted in the professionals' discourse.

Excerpts 1-2, drawn from interviews with the professionals in the North Church (the pastor and the parish educator), exemplify how the migrants are positioned as enabled citizens who are needed and embraced by the community.

\section{Excerpt 1:}

men sen är det här att få komma till en plats å få ett sammanhang, att få möta andra dels i samma situation liknande, att känna igen sej, att få byta erfarenheter, få nätverk å så vidare, men också att möta oss som har varit här i Sverige länge eller födda i Sverige, så de e mycket liksom mer egentligen än att lära sej språket; alltså vi vill ge mer egentligen å de tror jag att vi gör också, å att man skapar vänskap mellan människor; å nån som kommer å säjer "du jag har ingen bostad nu”, "men kom då och då”, brukar jag säja, "för då har du mycket folk här”; alltså att komma hit å få ett nätverk, få ett sammanhang, få människor man kan få stöd å hjälp av 
eller bara träffa å få liksom trevnad i livet; alltså de kan va ganska basalt å enkelt egentligen så; å de vill vi erbjuda på många olika sätt, till exempel genom svenskundervisningen

but then it is this to come to a place and feel connected, to meet other people in the same situation with whom you can identify, to share concerns and experiences networking and so on, but also to meet us who have been here in Sweden for a long time or are born in Sweden. So it's much more actually than learning the language; in fact we want to give more actually and I think we do that, and that you create friendship between people and someone who comes and says: "I have no housing at the moment", but "come then and then", I usually say, "because then there are many people here"; I mean to come here and get a network, be connected to people from whom you can get support and help or just meet and get sort of well-being in life; it can be very basic and simple actually and we want to give that in many different ways, for example through the Swedish language classes [Interview with pastor in the North Church].

\section{Excerpt 2:}

jag kämpar konstant för att eleverna ska veta att eleverna är en del av de här landet, vi behöver dej, du e behövd, du e välkommen hit, vi vill förstå dej

I struggle constantly to make the students know that they are part of this country: "we need you, you are needed, you are welcome here, we want to understand you" [Interview with parish educator in the North Church].

In these excerpts, an asymmetric power relationship between the migrant as the dispossessed and vulnerable in need of support (e.g. without housing, Excerpt 1) and the church as the helper can be gleaned through the professionals' accounts. At the same time, the excerpts illustrate the need for a spatial context in which people meet and "feel connected" (Excerpt 1), and in which the dispossessed is empowered to self-support, for example through networking with people in a similar life situation. The professionals give voice to aspects of reciprocity, in terms of creating relationships, taking responsibility and understanding the other (Excerpt 2, 'we want to understand you'). The pastor describes the church with its variety of activities as a setting in which to share concerns with people with whom one can identify, a setting in which participants create new discursive zones for belonging. The parish educator quotes what she says to the students on behalf of the Swedish community as she constantly struggles to make them understand that they are part of the new country. All this reveals that belonging to a community in 
the way it is conceptualized in the professionals' accounts in Excerpts 1-2 involves something more than solely receiving help from the host society or simply learning the language or adapting to the norms of the new cultural environment. The notion of networking is particularly interesting in this regard. The function of the church lies in aiding the meeting with and the search for help and comfort from not only the professionals, but also other people in similar circumstances.

Excerpts 3-4 illustrate how empowerment is enacted in practice in the professionals' interaction with migrants. In Excerpt 3, which is drawn from the Swedish language classes in the North Church, the migrants are explicitly told by the parish educator (whom I call Lisa) that they belong to the Swedish society. This observation was recurrently emphasised by the parish educator in her interaction with the students. Prior to this excerpt, the participants have been involved in explanatory work focusing on a Swedish sentence that one of the students in the class, Salem, had read aloud from his notebook ("Det dröjer lite innan man vänjer sig att leva i Sverige”, 'It takes some time before you get used to living in Sweden'). As part of this explanatory work, Salem translates pieces of the parish educator's word explanations from Swedish into Arabic for his classmates. The explanatory work is marked as completed, when Lisa reads aloud the sentence written on the board (lines 1-2). She then addresses the students with referential questions, thereby engaging them in topical talk (line 3-4).

Excerpt 3: "You belong here”. Participants: Lisa (parish educator); Salem, Omar and Inez (students).
1. Lisa: så de dröjer lite innan man vänjer sej vid so it takes some time before you get used
2. att leva i Sverige (1.5) to living in Sweden (1.5)
3. hur mycket tid tror ni att de tar? how much time do you think that it takes?
4. Salem har du vant dej vid att leva i Sverige? Salem have you got used to living in Sweden?
5. Salem: ja: : vill e:: (1.2) fem år $I:$ will e:: : (1.2) five years
6. Lisa: fem [år
five years
7. Salem: [to lära e: svenska. to learn e: Swedish
8. Lisa: å sen efter fem år [så får du bli, an' then after five years you can become,
9. Salem:
[efter fem år after five years


10. Lisa: svensk medborgare.= a Swedish citizen. =

11. Salem: =jag kan prata

= I can talk

12.

(1.1)

13. Lisa: precis. (0.5) du kan prata exactly. (0.5) you can speak

14. $\operatorname{duk}(\mathrm{h})$ an redan pra(h)ta «vadå jag kan pra(h)ta» you can al ready speak «hey I can speak»

15. $\quad$ du k(h) an ju redan pra(h)ta you can al ready speak can't you ((laughter in the class))

16. Omar: sarrlak khams esneen become-for-you-2SG-MAS five years you've been here for 5 years?

17. Salem: (xxx) akkelh[a att'allam ] ahkey (xxx) 1SG-tell-her 1SG-learn 1SG-talk (xxx) I tell her I'm learning to talk

18. Lisa: [de e underbart] it's wonderful

19. Lisa: de e underbart (.) du kan prata svenska redan it's wonderful (.) you can speak Swedish already

20. (0.5) $\underline{\mathrm{m}[\mathrm{en}}$ but

21. Inez:

[rah enseybak bill'ain will 1PL-hit-you in-DEF-eye we will envy you

22. Lisa: när duwhen you-

23. Inez: $(x x x x)$

24. Lisa: när duharwhen you've

25. Salem: (xxx) lessa'ma a'ref ( $x x x)$ still not 1SG-know ( $x x x)$ I still can't (speak Swedish)

26. Lisa: hhhprecis (0.4)

$h$ h h exactly (0.4) 
27. när du har bott här i fem år , when you have lived here for five years

28. Salem: ja

Yes

29. Lisa: då kan du bli svensk medborgare. then you can become a Swedish citizen

30. Student: ja

yes

31. Salem: *ja*

yes

*gazes at Lisa*

32. Lisa: +å de gäller alla+

an' that applies to everybody

+sweeps her arm over the class-

33. $(1.0)+$

$--->+$

34. Lisa: when you have lived here five years

35. with your residence permit ( 0.5$)$

36. you have the right to

37. become a Swedish citizen (0.4)

38. and even before that

39. +nobody can tell you you don' $t$

+waves index finger-

40. [belong here (0.4)

41. Inez: [akhathet eljinseyya

take-2SG-MAS DEF-citizenship

did you get citizenship

42. Lisa: +it's not true+ (.)

+waves index finger+

43. [you belong here as same as anyone else

44. Salem: $\quad[l a($.$) sarrley santain$

no (.) become-to-me-1SG two-years

no it's been two years

45. sarrley santain hown bas

I've been here for just two years

46. Lisa: you are part of this country

47. like the $(0.6)$ the rocks (.)

48. you are part of this country like the trees 
49.

you are part of this country like any other

person

50. Student: ja

yes

51. Lisa: nobody can tell you it is not your country $(0.5)$

52.

så de e jätteviktigt att vi vet

so it's very important that we know

53.

om ni tillhör Sverige

that you belong to Sweden

54.

lika mycke som Sverige tillhör oss (0.5)

as much as Sweden belongs to us (0.5)

55.

ni e alla en del av Sverige

you are all part of Sweden

This excerpt shows how a pedagogical project that starts as instruction and develops into a rhetorical plea emerges in and through the interaction in the classroom. The parish educator is building on a student's contribution to instruct the students about their right to apply for Swedish citizenship after five years of residence. The period of time that Salem claims that it will take for him to learn and to talk Swedish is equivalent to the length of residence in Sweden commonly required for migrants to apply for Swedish citizenship. Lisa however regards Salem as a competent speaker of Swedish already (lines 13-15 and 19). In lines 27 and 29, after a sequence in which the students interact in Arabic (lines 16-18, 21, 25), Lisa points out to Salem that after his five years in Sweden, he can become a Swedish citizen, which Salem confirms with an affirmative token while gazing at Lisa. As she sweeps her arm over the class to indicate the inclusion of all students, Lisa asserts everybody's right to Swedish citizenship (line 32; note that this is not true given that award of Swedish citizenship is conditional). The use of alla ('everybody') in Lisa's turn is what Pomerantz (1986) terms an extreme case formulation, a practice used to convince others to believe an idea. Here it is used by Lisa as a resource to support her project to include all students in her argumentation. From line 34 onwards, she pleads on behalf of the migrants for their civic rights in Sweden. With a switch to English (line 34), she pursues her line of argument: citizen or noncitizen, all students in the class belong to Sweden. In terms of inclusion, this language alternation helps Lisa to emphasize her plea that everyone belongs to Sweden, since the choice of English, which was frequently used as a lingua franca (Firth and Wagner 1997) in the class, possibly makes her plea more understandable. Waving her index finger back and forth in the air, she asserts that nobody can claim 
the opposite (line 39), emphasising the falseness of such a proposal (line 42). With the extreme case formulation nobody she counters any possible challenge to the legitimacy of her claim that everybody belongs to Sweden, as if addressing a public antiimmigrant discourse that might be invoking the illegitimacy of the claim. The turn in lines 46-49 involve parallelism and similes, and the extreme case formulation any other person. These are rhetorical devices that together with embodied resources reinforce her argument: the students belong to this country as much as the rocks and the trees do, as much as any other person. Finally, in line 52, Lisa includes herself as a member of the category of people for whom this argument is a great concern (see the Swedish personal pronoun vi, 'we').

The pedagogical project enacted by the parish educator in this excerpt, enhanced through the use of different languages and modalities (spoken and embodied resources), serves to empower the students as enabled and competent citizens. Belonging to the country of residence is cast as a human right that includes all students, as much as any living organism, irrespective of length of residence or institutionally documented citizenship.

In Excerpt 4, empowerment is enacted through the professional's stancesharing, affiliative recipient responses that endorse the migrant's perspective. Stance is a term used to indicate a fundamental property of communication that is achieved and is emergent in interaction as acts of evaluation invoking moral and social orders (Jaffe 2009). In the CA literature stance is defined as "the teller's affective treatment of the events he or she is describing” (Stivers2008: 37) and refers to a positioning accomplished through conduct. The excerpt involves the pastor in the Hill Church (whom I call Sune) and is drawn from a video-recorded session in the language café that is run two days a week by the church. In interviews, the pastor reports that he is intent on talking with the café visitors about their current life situation and their needs, as for instance, finding employment. As a member of the organizing committee of the asylum project, he is very much engaged in the café, where he attends almost every session. In this particular case, the pastor is sitting with a group of migrants from Syria who often discuss difficulties in finding a job in Sweden. In lines not reported here, the participants have been discussing a fair for unemployed people, when one of the participants, Tarek, launches a trouble -telling concerning his experiences with employment offices. Tarek reports that every office clerk in the employment agencies he has visited or in the apprenticeships he has attended says that he is old: since he has turned 60, he cannot work anymore. The excerpt below starts with the pastor trying to engage Tarek in further topical talk that elaborates on Tarek's telling of his experiences. 
Excerpt 4. "Plumbers are needed.” Participants: Sune (pastor); Tarek (migrant/ cafévisitor).

1. Sune: va skulle du själv vilja arbeta me. what would you like to work wi th yourself.

2. Tarek: ja jobbade ${ }^{\circ} \mathrm{tj}^{\circ}{ }^{\circ}(0.2)$ cirka tjugo år, I worke: $d^{\circ} t^{-}{ }^{\circ}(0.2)$ about twenty years,

3. Sune: ja, yes,

4. Tarek: rörmokare i mitt ${ }^{\circ}$ land $^{\circ}$. plumber in my ${ }^{\circ}$ country ${ }^{\circ}$.

5. Sune: rörmokare. [precis. plumber. exactly

6. Tarek: [ja. yes.

7. Tarek: å ja går de här s-e: : : : (1.3) an' I go this eh $s-e:::: h(1.3)$

8. Tarek: eh: :h två gånga prektik, e: $h$ apprenticeship twice,

9. Sune: $a: h$. yes.

10. Tarek: tre månader, tre månader, three months, three months,

11. Sune: ah. yes.

12. Tarek: å han [säjer an' he says

13. Sune: [du har haft två praktik, you have had two apprenticeships,

14. Tarek: ah.

yes.

15. Sune: tre månader. three months.

16. Tarek: ah.

yes.

17. Sune: a:h. (. ) va [säjer dom [då till dej. ye:s.(.) what do they say to you then.

18. Tarek: [a:h. [du gammal. ye:s. you old.

19. du kan inte $\left(p^{-}\right)$jobba. you cannot $\left(p^{-}\right)$work. 
20. Sune: säjer dom de till dej.

do they say that to you.

21. Tarek: ah. den slu+tar prektik du k(h)an inte jo(h)bb(h)a(h) yes. it ends apprenticeship you cannot work

22. $\quad+(($ Sune purses lips downward $))$

23. Tarek: +duk(h)an inte jo(h)bb(h)a(h)

you cannot work

24. $+(($ Sune shakes head $))$

25. hu hu hu hu

26. Sune: nej. de e tråkigt.

no. it's sad.

27. Tarek: ja. de e +mycket tr[åkigt. yes. it is very sad.

28. $+(($ Sune raises eyebrows $))$

29. Sune:

[för ja vet, because I know,

30. (0.3)

31. Tarek: ja: [vet

I know!

32. Sune: [att that

33. (0.3)

34. Sune: å de vet du också an' you know that as well,

35. Tarek: *((nodding) $) *$

36. *ah.*

yes.

37. Sune: rör+mokare plumbers,

38. $\quad+(($ nodding $))$

39. Tarek: *((nodding $))$

$40 . \quad * a: h$. yes.

41. Sune: de behövs. they are needed.

42. Tarek: ja. behövs. yes. needed.

43. Sune: de e: brist. they are lacking. 
In this excerpt, Tarek engages in a telling about his efforts to find a job in Sweden. Since Tarek had worked as a plumber in his country, he would like to work as a plumber in Sweden. He reports attending two plumbing apprenticeships (line 8), each lasting three months (line 10). The apprenticeship ended with the conclusion that he is old and cannot work. This is the most dramatic element of Tarek's story and a point of high emotive involvement. The pastor negatively assesses Tarek's experience with “de e tråkigt." ('it is sad', line 26) and manifests his stance through embodied actions (pursed lips, line 22 and head shake, line 24), thereby affiliating with Tarek. Tarek expresses his agreement with an upgraded assessment (“de e mycket tråkigt”, 'it is very sad', line 27).

In this micro-moment of interaction, the migrant voices his complaints about employment offices positioning him as too old for the labour market. The pastor takes stance against this institutional age policy by assessing it as illogic and even unfair. This makes Tarek's troubles and the unfortunate consequences this policy has on Tarek's professional life even more dramatic. What happened to Tarek is sad because plumbers are actually needed (lines 41 and 42) as there are too few of them (line 43) in Sweden. The pastor shows his understanding of Tarek's troubles through his explicit assessment of Tarek's situation as sad, and his strong epistemic positioning as a participant who knows for a fact that people with Tarek's skills are needed.

In sum, Excerpts 3-4 provide evidence for the practices through which the professionals affirm, confirm and thereby empower the migrants. The parish educator steps out of her institutional role as a teacher and becomes an advocate for migrants' incontestable right to belong to Sweden. The pastor shares the migrant's stance as he takes his side against an illogical age policy that is adopted in the country of residence. In both excerpts, the migrants are portrayed as competent individuals whose qualifications are needed.

\subsection{Negotiating belonging beyond cultural and linguistic boundaries}

As multi-ethnic institutions whose members and visitors come from various traditions and speak different languages, the churches struggle with integration, with the joining of diversity into one community. The North Church and the South Church are divided into several congregations representing different language groups holding their own, separate services. This means that the Sunday service and other gatherings are held in several languages alongside Swedish at different hours on a regular basis. Specifically, the North Church has been offering service and gatherings in English to reach West-Africans (since 2008); in the South 
Church some activities have been held in Arabic since the 1970s when the municipality received their first influx of Syrians. In the Hill Church, a multi-ethnic Greek-Orthodox parish has been offering Saturday masses in Arabic since the 2015 crisis. The migrants who attend this mass are Christian Syrians, many of whom are regular visitors in the language café organized by the Hill Church.

In the interviews, the professionals emphasise that, even though the churches are organized in language groups, they constitute one community. The data presented in this study attest that the professionals have adopted practices that create a sense of belonging to the same community, practices that involve functional use of different languages. In the Hill Church, an ecumenical service is celebrated once a month, in Swedish and Arabic alternately. In the excerpt below (Excerpt 5), the pastor in the South Church reports how they use interpreting in the service as a means to indicate oneness.

\section{Excerpt 5:}

å vi försöker å tolka på svenska gudstjänsterna; vi läser på söndans huvudgudstjänst läser vi alltid evangelietexten på arabiska till exempel, å försöker- å ofta går pastor Irfan in, eller ofta men nån gång e: i månaden kanske å predikar på söndan för att vi ska kunna markera detta samhörigheten, de e EN församling här, men de e två språkgrupper

an' we try to interpret in the Swedish services; we read on the Sunday main service we read the gospel in Arabic for instance, an' try- an' often pastor Irfan steps in, or often but some time $\mathrm{u}$ :h per month perhaps, an' gives the sermon on Sunday in order to indicate this belonging. It is ONE parish here, but there are two language groups [Interview with pastor in the South Church].

At the same time, the professionals in the North Church report that it is common for the attendees in the language classes to have a religious affiliation and to integrate their religious practices in everyday life. Many are Muslims, but there is also a group of Christians, who regularly attend the Sunday service. In Excerpt 6, the parish educator points out the oneness among them.

Excerpt 6:

e: jag har ju sagt hur många gånger som helst till eleverna att vi e alla lika, alla olika, å de e fantastiskt, å de e därför som vi alla behövs; vi måste liksom hjälpas åt å vi- de finns ingen skillnad på oss utan vi e alla människor, alla hjälps åt, alla e liksom ett, e:: å de jag gör, de inte så att jag (du ska) så här: "du ska glömma alla dina språk, du ska bara kunna svenska”, utan precis tvärtom, ”ja vill ge dej ett språk till, å jag vill inte ta bort dina sociala koder som du har från ditt hemland eller från din kultur, utan jag vill ge dej nya sociala koder, nya kulturella koder 
I have told the students endless of times that we are all similar, all different, an' it's fantastic an' that's why all of us are needed; we have to kind of help each other an' we- there is no difference between us but we are all human beings, everybody help each other, everybody is kind of one, u::h an' what I do, it's not that I (you must) like this: "you should forget all your languages, you shall only know Swedish", but exactly the opposite: “I want to give you one more language, an' I don't want to delete your social codes that you have from your home country or from your culture, but I want to give you new social codes, new cultural codes" [Interview with parish educator in The North Church].

The parish educator quotes what she constantly tells the students: although they are different with respect to languages and cultures, they are interconnected with each other as human beings. Excerpt 7, which is drawn from the Swedish language classes, illustrates how this pedagogy of interconnectedness that enhances human commonality that goes beyond language is negotiated in the classroom interaction. In the literature on translanguaging, going beyond languages refers to "transforming the present, to intervening by reinscribing our human, historical commonality in the act of translanguaging” (Wei 2018: 24; see also Canagarajah 2018; García and Wei 2014). The interaction emerges during an exercise on Swedish vowels. Prior to this excerpt, the participants have been engaged in a word explanation sequence focussing on the meaning of the Swedish word tåg ('train') that appears on an exercise sheet. A student in the back row in the class translates the word into Albanian to the classmate sitting next to her. She repeats the word in Albanian, tren ('train'), and points to the board where the Swedish word tåg is written.

Excerpt 7: "Some small small connection between us". Participants: Lisa (parish educator); Irma, Salem, and Aida (students); other students.

1. Lisa: där hörde ja ännu en koppling ( 0.5$)$

there I heard one more connection (0.5)

2. va heter tåg

what is train

3. Aida: tren.

train

4. Lisa: tren?

train

5. Aida: $\mathrm{m}: \uparrow \mathrm{m}$.

6. Lisa: +de heter likadant på spanska+

it's the same in Spanish

+repeated pointing to herself and students+

7. Lisa: +stretches out her arm with raised thumb+ 


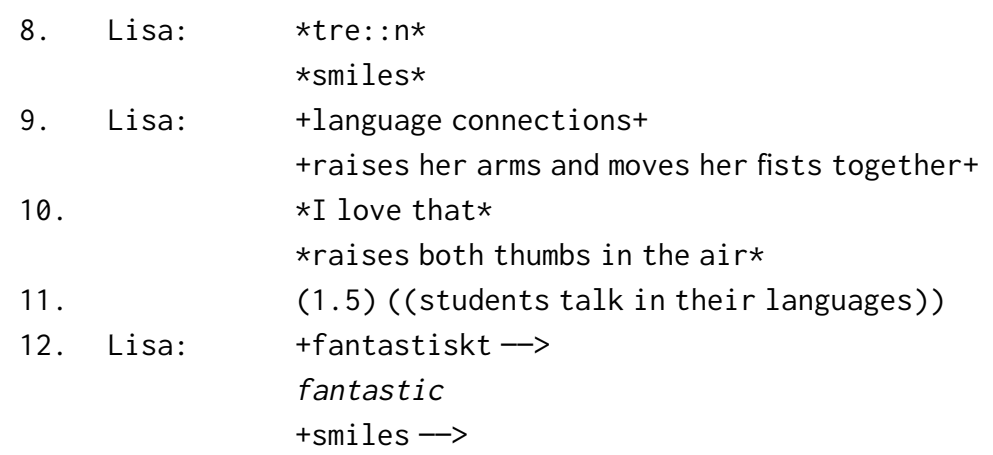

13. (6.0) ((students talk in their languages))

14. Lisa: å hitta e: apropå språket (.) de e så roligt an' find $u$ : $h$ regarding the language (.) it's so fun

15. å hitta kopplingar mellan våra språk $(0.5)$ de e to find connections between our languages (0.5) it's

16.

17. ofantligt roligt å hitta dom här små små små orden enormously fun to find those small small small words som kopplar samman våra språk å gör att de blir that connect our languages an' make it

18. roligare å lättare att lära sej (0.4) å de e more fun and easier to learn (0.4) an' it's

19. särskilt roligt å se när de lyser upp i våra ögon particularly fun to see when our eyes are lightening

20. att de liksom that it like

21. Lisa: $(0.8)+$ snaps with fingers+

22. Lisa: har (0.4) fattat have grasped

23. å att vi har hittat en koppling (. ) de tycker ja an' that we have found a connection (. ) that I find

24. e extra roligt när man tänker på att extraordinary fun when you consider that

25. språken e så skilda annars. (.) the languages are so different otherwise (.)

26. å att vi kan hitta nån li ten liten koppling an' that we can find some small small connection 27. mellan oss. (.) de e fantastiskt (0.4) between us. (.) that's fantastic (0.4) 
28.

så tåg (0.8) va heter de på arabiska (. ) tåg

so train (0.8) what is that in Arabic (.) train

\section{Salem: tåg \\ train}

30. Students: qettar

train

((students repeat the word qettar one by one and in chorus))

((students repeat the word for 'train' aloud in their different languages during 6s))

31. Lisa: så var nånstans heter de tren?

so where is it tren

32. Students: tren

train

33. Students: treno grekiska treno (.) treno

train Greek train (. ) train

34. Lisa: nähä. å på albanska?

oh really. an' in Albanian

35. Students: tren

train

36. Lisa: fantastiskt

fantastic

37. Irma: *same*

*smiles and nods*

38. Lisa: underba:rt

wonderful

In this excerpt, the participants not simply go between different languages, they also go beyond them (cf. Wei 2018). The parish educator (Lisa), who is bilingual in Swedish and Spanish, picks up the word tren from Aida and her classmate's interaction, pointing out that it is the same in Spanish (line 6). This interconnectedness between languages is emphasised with gestural resources (pointing gestures to herself and to the students in the back row, indicating the connection between them, line 6; fists together with raised arms, line 9). To indicate appraisal of this interconnectedness, she stretches out her arm with a raised thumb (line 7) and holds up both thumbs in the air (line 10). This appraisal of connections between their languages, even though small, embellished with an abundance of high-grade assessments, enhances the commonality between the participants as human beings, despite the great differences that exist among them (see lines 24-26). In line 28, Lisa addresses the students, asking them what "train" is in their languages. The students 
respond with engagement, calling out the word for "train" in their different languages, one by one and in chorus. It is shown that the Arabic word is quite different from tren in Albanian and Spanish, whereas Greek has treno, providing one more connection, which Lisa treats as praiseworthy (lines 36 and 38). Irma, one of the students in the back row, confirms this connection between Albanian and Greek by saying "same" (line 37) in English, while smiling and nodding.

To sum up, Excerpts 5-7 illustrate the practices that the professionals have developed to negotiate spaces for belonging beyond cultural and linguistic boundaries. These practices involve the integrated use of different languages, but also a process of knowledge construction that "goes beyond language(s)" (Wei 2018: 15). Through her practices (highlighting and praising interconnectedness, advocating for a pedagogy that fosters the development of multilingual individuals), the parish educator enhances the participants' experiences as language users, but also their commonality as human, social beings who create for themselves a social space for belonging.

\section{Concluding discussion}

In this article, I have explored how professionals in three evangelical churches in Sweden engage with migrants in their everyday work in a multilingual environment. The practices of three pastors, a deacon and a parish leader and their everyday interaction with migrants in various activity contexts have been examined. The concern for ecological validity (Cicourel 1985, 1992), involving a triangulation of ethnographically contextualized data sources resulting from long periods of observations and recordings, has provided knowledge about routine activities and practices in the churches. Using seven data excerpts from interviews and video recordings, analysed through an emic perspective afforded by the methodological tools of CA (Sidnell and Stivers 2013), I have shown how the professionals envision their role as providers of spaces for belonging (Lee 2015; see also Bakkær Simonen 2017; Fauser 2020) in which the migrants can experience social well-being and feel embraced by the community, and how they creatively utilize different modalities and languages in negotiating these spaces in and through interaction (e.g. Lee 2015).

The findings from this study highlight the role of the church within the public sphere under the changing conditions of globalization. The analysed data excerpts provide insight into the church as an increasingly multilingual work environment. The three churches in focus in this study illustrate the way migration affects how church professionals engage the world around them in agency-funded projects (cf. Salmonsson 2016; Snyder 2012). 
A crucial finding in this study concerns how commonality between the participants as human, social beings is negotiated. Advocating for a pedagogy that fosters the development of multilingual individuals like the parish educator in this study does is not new. Moreover, there is a growing body of research that shows how multilinguals in a variety of settings go between languages and modalities. It has been shown how the professionals in this study make use of multilingual resources to enhance empowerment and promote inclusion (see e.g. the parish educator's switch to English in Excerpt 3). At the same time there is a need for critical awareness of language practices. Whereas moving between languages can be used as a resource to secure inclusion, the same practices can also lead to the exclusion of (a) physically present person/s (cf. Jansson et al. 2017).

The participants in this study do something more than going between languages: they also go beyond languages (Canagarajah 2018; García and Wei 2014; Wei 2018). The practices of the pastor, and perhaps most importantly the parish educator, convincingly show how belonging is negotiated beyond linguistic boundaries, thereby establishing a community that goes beyond language. Two different dimensions of belonging are invoked in the empirical data: empowering the vulnerable and negotiating belonging beyond linguistic and cultural boundaries. Specifically, through their practices, the church professionals enhance the participants' experiences as language users, but also their commonality as human, social beings and enabled citizens, who create for themselves a social space for belonging. We have observed examples of the professionals' practices as they highlight the migrants' civic rights as Swedish citizens (Excerpt 3), as they display understanding of the migrant's situation as problematic while taking stance against an unfair age policy that puts a skilled worker out of the job market (Excerpt 4), and as they praise interconnectedness (Excerpt 7). The participants in the language class are in fact using different languages (see Excerpt 7), albeit in order to identify connections among them. The parish educator utilizes these connections between languages to enhance belonging. Viewed through the theoretical lens of translanguaging, the participants thereby transform the present, i.e. the existence of large, seemingly unbridgeable differences, and by so doing reinscribe their historical commonality as thinking human beings (cf. Wei 2018: 24).

The professionals' enhancement of belonging in this study is worth considering given the fact that Sweden is moving towards an ever-tougher asylum policy since the 2015 crisis, when the country received a great influx of refugees. An increasing anti-immigrant sentiment has created a hostile environment, which has led migrants to feel insecure about their settlement status and to question their sense of belonging. This casts the parish educator's rhetorical plea concerning everyone's right to Swedish citizenship (Excerpt 3) as a counter discourse to public hate speech against asylum-seekers. There may of course be other views on the 
parish educator's extreme case discourse; for example, some might point out how such a discourse could create false pretensions about civic rights in Sweden and therefore cause possible problems. Nevertheless, the parish educator's plea resonates well with the migrants' perceived vulnerability to marginalization and social exclusion (e.g. Fauser 2020), as shown in Excerpt 1. Settlement, not least in terms of housing and employment, but also with respect to education and language, was a great concern among the migrants.

Ultimately, the findings from this study provide evidence for how church professionals creatively enact their biblical commands to remember aliens and strangers through faithful actions (e.g. Graham et al. 2019; Snyder 2012; Zink 2019), and how they thereby engage with migrants in their everyday work in a multilingual environment. Their practices illustrate how they respond to the needs of migrants in vulnerable positions, but also and most importantly how they adopt practices of empowerment to strengthen the vulnerable.

Acknowledgements: I am grateful to the employees and the migrants who participated in this study.

\section{Appendix 1: Transcription conventions (see Jeffer- son 2004)}

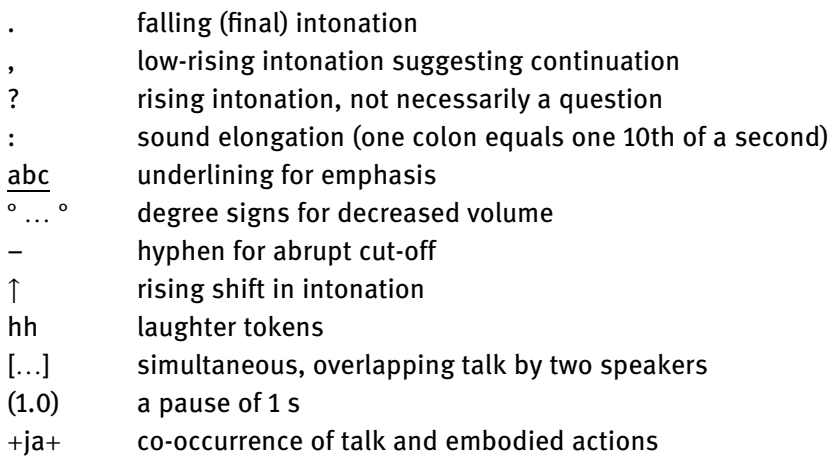

\section{Appendix 2: Morphological gloss abbreviations}

$\begin{array}{ll}\text { SG } & \text { singular } \\ \text { PL } & \text { plural } \\ \text { DEF } & \text { definite }\end{array}$




$\begin{array}{ll}\text { MAS } & \text { masculine } \\ 1 & \text { first person } \\ 2 & \text { second person } \\ 3 & \text { third person }\end{array}$

\section{References}

Bakkær Simonen, Kristina. 2017. Does citizenship always further immigrants' feeling of belonging to the host nation? A study of policies and public attitudes in 14 western democracies. Comparative Migration Studies 5(3). 1-7.

Bech, Emily Cochran, Karin Borevi \& Per Mouritsen. 2017. A 'civic turn' in Scandinavian family migration policies? Comparing Denmark, Norway and Sweden. Comparative Migration Studies 5(7). 1-24.

Blackledge, Adrian, Angela Creese \& Rachel Hu. 2015. Voice and social relations in a city market. Working Papers in Translanguaging and Translation (WP.2). 1-118.

Blommaert, Jan. 2010. The sociolinguistics of globalization. Cambridge: Cambridge University Press.

Canagarajah, Suresh. 2018. Translingual practice as spatial repertoires: Expanding the paradigm beyond structuralist orientations. Applied Linguistics 39(1). 31-54.

Chao, Xia. 2020. Language and identity: An inquiry of church-based U.S. citizenship education for refugee-background Bhutanese adults. Language and Education 34(4). 311-327.

Cicourel, Aaron V. 1985. Text and discourse. Annual Review of Anthropology 14. 159-185.

Cicourel, Aaron V. 1992. The interpenetration of communicative contexts: Examples from medical encounters. In Alessandro Duranti \& Charles Goodwin (eds.), Rethinking context: Language as an interactive phenomenon, 291-310. Cambridge: Cambridge University Press.

Cummins, Jim. 2000. Language, power and pedagogy. Bilingual children in the crossfire. Clevedon: Multilingual Matters.

Fauser, Margit. 2020. Emigrant citizenship, privileged local belonging and the option to return: Germans on the Turkish coast. Comparative Migration Studies 8(7). 1-17.

Firth, Alan \& Johannes Wagner. 1997. On discourse, communication and (some) fundamental concepts in SLA research. Modern Language Journal 81. 285-300.

Flescher, Andrew Michael \& Daniel L. Worthen. 2007. The altruistic species. Scientific, philosophic and religious perspectives of human benevolence. Philadelphia \& London: Templeton Foundation Press.

García, Ophelia \& Li Wei. 2014. Translanguaging: Language, bilingualism and education. London: Palgrave Macmillan.

Graham, Elaine, Heather Walton \& Frances Ward. 2019. Theological reflection methods, 2nd edn. London: SCM Press.

Gregory, Eve, Halimun Choudhury, Arani Ilankuberan, Amoafi Kwapong \& Malgorzata Woodham. 2013. Practice, performance and perfection: Learning sacred texts in four faith communities in London. International Journal of the Sociology of Language 220. 27-48.

Jaffe, Alexandra. 2009. Introduction. The sociolinguistics of stance. In Alexandra Jaffe (ed.), Stance: Sociolinguistic perspectives, 3-28. Oxford: Oxford University Press.

Jansson, Gunilla, Cecilia Wadensjö \& Charlotta Plejert. 2017. Managing complaints in multilingual care encounters. Multilingua 36(3). 313-346. 
Jefferson, Gail. 2004. Glossary of transcript symbols with an introduction. In Gene H. Lerner (ed.), Conversation analysis: Studies from the first generation, 13-31. Amsterdam: John Benjamins.

Kramsch, Claire J. 1993. Context and culture in language teaching. Oxford: University Press.

Lähdesmäki, Tuuli, Tuija Saresma, Kaisa Hiltunen, Saara Jäntti, Nina Sääskilahti, Antti Vallius \& Kaisa Ahvenjärvi. 2016. Fluidity and flexibility of "belonging": Uses of the concept in contemporary research. Acta Sociologica 59(3). 233-247.

Lee, Hakyoon. 2015. Telling stories and making social relations: Transnational women's ways of belonging in intercultural contexts. Applied Linguistics 36(2). 174-193.

Marfleet, Philip. 2011. Understanding sanctuary: Faith and traditions of asylum. Journal of Refugee Studies 24(3). 440-455.

Miller, Donald E. \& Tetsunao Yamamori. 2007. Global pentecostalism: The new face of Christian social engagement. Erwing, New Yersey: University of California Press.

Norton, Bonny. 2000. Identity and language learning. Gender, ethnicity and educational change. Harlow: Pearson Education Limited.

Pastor, Ana Maria \& Anna De Fina. 2005. Contesting social place. In Mike Baynham \& Anna De Fina (eds.), Dislocations/relocations: Narratives of displacement, 36-60. Manchester: St. Jerome Publishing.

Pomerantz, Anita. 1986. Extreme case formulations: A way of legitimizing claims. Human Studies 9. 219-229.

Prochaska, Frank. 2006. Christianity and social service in modern Britain: The disinherited spirit. Oxford: Oxford University Press.

Ruiter, Stijn \& Nan Dirk De Graaf. 2006. National context, religiosity and volunteering: Results from 53 countries. American Sociological Review 71. 191-210.

Salmonsson, Lisa. 2016. Stockholms församlingars arbete mot segregation. [Stockholm parishes' work against segregation]. Stockholm: Svenska kyrkan, Stockholms stift.

Sidnell, Jack \& Tania Stivers. 2013. Handbook of conversation analysis. Oxford: Wiley-Blackwell.

Simpson, James. 2020. Navigating immigration law in a "hostile environment": Implications for adult migrant language education. Tesol Quarterly 54(2). 488-511.

Snyder, Susanna. 2012. Asylum-seeking, migration and church. Farnham \& Burlington: Ashgate Publishing Company.

Steensland, Brian \& Philip Goff. 2013. Introduction. In Brian Steensland \& Philip Goff (eds.), The new evangelical social engagement, 1-27. New York: Oxford University Press.

Stivers, Tania. 2008. Stance, alignment and affiliation during storytelling: When nodding is a token of affiliation. Research on Language and Social Interaction 41(1). 31-57.

Wagndal, Mats. 2016. Många ideella organisationer engagerade i flyktingmottagning. [Many nonprofit organizations engaged in the reception of refugees]. SCB: 2016:46. https://www. famna.org/ideella-aktorer-om-arbetet-med-flyktingmottagandet-hosten-2015/ (accessed 17 January 2021).

Wagner, Johannes. 2018. Multilingual and multimodal interactions. Applied Linguistics 39(1). 99-107.

Wei, L. 2018. Translanguaging as a practical theory of language. Applied Linguistics 39(1). 9-30.

Zink, Jesse. 2019. Anglican theology in the midst of migration crisis. Journal of Anglican Studies 17. 31-47. 